\title{
Modelling woody material transport and deposition in alpine rivers
}

\author{
B. Mazzorana $\cdot$ J. Hübl $\cdot$ A. Zischg $\cdot$ A. Largiader
}

Received: 6 December 2008/ Accepted: 19 December 2009/Published online: 19 January 2010

(C) The Author(s) 2010. This article is published with open access at Springerlink.com

\begin{abstract}
Recent flood events in Switzerland and Western Austria in 2005 were characterised by an increase in impacts and associated losses due to the transport of woody material. As a consequence, protection measures and bridges suffered considerable damages. Furthermore, cross-sectional obstructions due to woody material entrapment caused unexpected flood plain inundations resulting in severe damage to elements at risk. Until now, the transport of woody material is neither sufficiently taken into account nor systematically considered, leading to prediction inaccuracies during the procedure of hazard mapping. To close this gap, we propose a modelling approach that (1) allows the estimation of woody material recruitment from wood-covered banks and flood plains; (2) allows the evaluation of the disposition for woody material entrainment and transport to selected critical configurations along the stream and that (3) enables the delineation of hazard process patterns at these critical configurations. Results from a case study suggest the general applicability of the concept. This contribution to woody material transport analysis refines flood hazard assessments due to the consideration of woody material transport scenarios.
\end{abstract}

Keywords Woody material transport - Natural hazards · Hazard mapping · Risk assessment

B. Mazzorana $(\bowtie)$

Department of Hydraulic Engineering, Autonomous Province of Bolzano South Tyrol, Bolzano, Italy e-mail: bruno.mazzorana@provinz.bz.it

B. Mazzorana · J. Hübl

Institute of Mountain Risk Engineering, University of Natural Resources and Applied Life Sciences, Vienna, Austria

A. Zischg $\cdot$ A. Largiader

Abenis AG, Chur, Switzerland

A. Zischg

Abenis Alpinexpert srl, Bolzano, Italy 


\section{Introduction}

Socio-economic developments in European mountain environments and related forelands are reflected in increasing settlement and economic activities in areas affected by natural hazards (Fuchs and Holub 2007). Consequently, considerable economic losses have resulted in recent years from events (Mitchell 2003; Autonome Brovinz Bozen-Südtirol 2006; Oberndorfer et al. 2007) despite the efforts made towards the mitigation of flood hazards and the reduction of specific risks (Fuchs and McAlpin 2005). At critical stream geometry configurations in mountain streams (e.g., bridge cross sections), a remarkable increase in process intensities could be attributed to woody material transport phenomena (e.g., Diehl 1997; Lyn et al. 2007). Due to the general necessity of assessing natural hazards and risks in a reproducible manner, guidelines for hazard mapping were defined in European countries (e.g., BUWAL 1998; Autonome Provinz Bozen-Südtirol 2006), thereby providing milestones with respect to the quality of integral risk management. The major starting point for managing risk from an integral point of view is the deduction and systematic construction of consistent and reliable scenarios. However, subjective assumptions on relevant impact variables such as woody material transport intensities on the system-loading side and response mechanisms at critical configurations often cause biases and inaccuracies in the results. Considering the hazardous effects of woody material transport, clear indications emerged from the analyses of the debris flow and flood events that occurred recently in several Alpine regions (e.g., Bänziger 1990; Rickli and Bucher 2006). At critical stream geometry configurations (e.g., bridge locations), the transported woody material is repeatedly entrapped. In addition to increasing the loading conditions on the structural components of the bridges (e.g., piers, abutments and superstructure), overflowing is likely to occur more frequently. In order to assess these phenomena, this paper aims at contributing to a systematic investigation of woody material recruitment processes, an evaluation of the propensity for woody material entrainment and transport to critical configurations, and a detection of hazard process patterns at these critical configurations during extreme floods. The analysis of such elements is indispensable for comprehensive flood hazard assessments and for optimizing forest management strategies. Moreover, knowledge about the quantity of woody material, the main woody material pathways in the stream channel and the main places of deposition is fundamental for the design of resilient protection systems and for optimised emergency planning. In order to approach problems emerging from in-stream structures, a detailed study of the damage potential has been carried out by Diehl (1997). The relation between the flow resistance due to the presence of large woody debris (LWD) and increased inundation frequency has been analysed in detail by Shields et al. (2001). New insights into the dynamics of wood transport in streams have been achieved by flume experiments (Rickenmann 1997; Braudrick et al. 1997; Braudrick and Grant 2000, 2001; Degetto 2000; Haga et al. 2002; Curran and Wohl 2003; Bocchiola et al. 2006). The interaction of woody material transport with protection measures has been investigated with a special focus on check dams (Bezzola et al. 2004; Lange and Bezzola 2006) and on rope nets (Rimböck and Strobl 2002).

Acknowledging the fact that hazard impacts at critical configurations along the stream could be interpreted as effects of a complex process interaction field, the main objective of this paper is to propose a modelling concept for the analysis of the following key aspects in considering woody material transport in flood hazard mapping: 
1. Disposition: Wood stand productivity and dead wood production in the recruitment areas are important factors that determine the disposition for woody transport phenomena in mountain streams.

2. Intensity of wood-flood interaction: Recruitment processes directly connected to the dynamics of wood-flood interaction become relevant. Recruitment processes due to wood-flood interaction can be attributed directly to hydrodynamic pressure loading and subsequent breakage of the stems. Moreover, morphodynamics such as stream bed erosion and aggradation and side erosion plays a relevant role (e.g., Abbe et al. 1997; Hildebrand et al. 1997; Gurnell et al. 2000; Keim et al. 2002; Montgomery and Piegay 2003; Comiti et al. 2006). In fact, the erosive action of the current is responsible for the scouring of root wads which in turn induces tree toppling.

3. Entrainment and transport of the woody material: The intensity of the flood process, in terms of flow depths and flow velocities, has to be considered as a critical parameter.

4. Interaction phenomena at critical channel geometry configurations: Significant in this context are woody material entrapment and the related consequences, e.g., bridge failures due to hydrostatic and hydrodynamic overloading. Because of the complexity of the involved process chains, magnitude-frequency-related considerations deserve close attention.

Given earlier, the developed conceptual structure comprises: (1) criteria for the localization and classification of woody material recruitment areas as well as the assessment of the woody material recruitment volumes; (2) a computational procedure for woody material entrainment processes; (3) a computational scheme for woody material transport, deposition and remobilization dynamics and (4) an analysis procedure of the interaction phenomena involving transported woody material occurring at critical stream configurations.

Data were implemented into a GIS environment. Subsequently, we tested the GIS application for reconstructing woody material recruitment, transport and deposition patterns during a design event with a reoccurrence period of 300 years and compared it with a flash-flood event occurred in 1987 in the Passirio/Passer River in South Tyrol (Northern Italy).

\section{Theoretical background}

Throughout the paper, we will consider a wood-covered flood plain region as a system, $\Omega$, as shown in Fig. 1. The system is confined at the downstream side by the outflow boundaries, $\Gamma_{\text {out }}$, and at the upstream side by the inflow boundaries, $\Gamma_{\text {in }}$. To simplify matters, these boundaries are assumed to be invariant. Furthermore, it is supposed that the material flux exchanges (e.g., discharge, sediment rates and wood material amounts) within the environment are taking place at these boundaries. At the margins, the system is confined to lateral flood plain boundaries, namely the slopes of the mountains. The system consists of stocks or storage compartments and flows or fluxes. Three storage compartments are defined as (1) sediment storage, $\left(X_{\Omega}^{1}\right)^{t}$, (2) water storage, $\left(X_{\Omega}^{2}\right)^{t}$ and (3) wood material storage, $\left(X_{\Omega}^{3}\right)^{t}$. The corresponding fluxes within the system and at the inflow boundaries are: (1) sediment fluxes, $\left(\Delta_{\Omega}^{1}\right)^{t}$ and $\left(\Delta_{\Gamma}^{1}\right)^{t} ;(2)$ water fluxes, $\left(\Delta_{\Omega}^{2}\right)^{t}$ and $\left(\Delta_{\Gamma}^{2}\right)^{t}$; and (3) woody material fluxes, $\left(\Delta_{\Omega}^{3}\right)^{t}$ and $\left(\Delta_{\Gamma}^{3}\right)^{t}$.

Each flood can be intended as a disturbance of the system, and the effects of a certain flood event depend also on the settings given by the previous floods. As a consequence at 


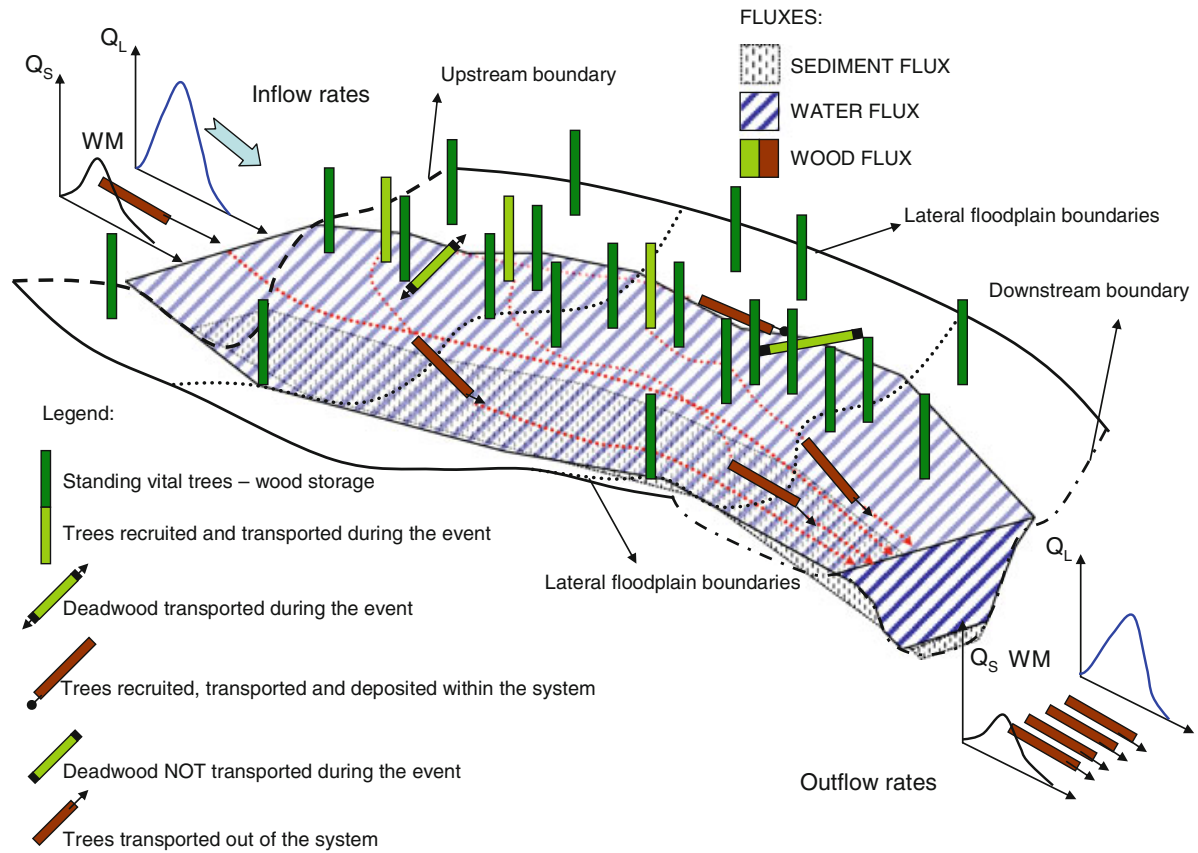

Fig. 1 Wood, sediment and fluxes and system dynamics

the beginning of each flood event, $t_{i}^{0}$ with $i=1, \ldots, N$, a specific set of initial conditions, $\left(X_{\Omega}^{j}\right)_{i}^{t_{0}}$ and $\left(\Delta_{\Omega}^{j}\right)_{i}^{t_{0}}$, with $j=1,2,3$ and inflow boundary conditions, $\left(\Delta_{\Gamma}^{j}\right)_{i}^{t}$, have to be considered.

The simulations of the material fluxes taking place within the considered system during successive extreme events would require the solution of distinct boundary conditions and initial value problems. Between successive extreme events, the morphodynamical development as well as the growth of the wood stocks has to be monitored in order to correctly assess both the initial and boundary conditions. In the following subsections, a concise summary of the main findings regarding woody material recruitment, entrainment and transport are given.

\subsection{Woody material recruitment}

Rickli and Bucher (2006) identify the following relevant recruitment processes from hill slopes:

1. Bank erosion: through the shear stress exerted on the wetted perimeter of the cross section of the channel, erosion processes occur along the banks and alter the static equilibrium of the trees. Synchronisms between debris flows, flood events and the earlier mentioned woody material recruitment processes are quite probable.

2. Wind-throw: strong wind conditions can either destabilise the trees that consequently fall as a whole into the channel or lead to the recruitment of the epigeous parts if their stems break under the wind loading. May and Gresswell (2003) point out that falling trees with a horizontal distance to the channel that exceeds their height can exert a destabilizing action on other trees (e.g., knock-on effect). 
3. Snow loading: the pressure exerted by snow, in particular wet snow in spring and autumn, can cause stability problems to broad-leaved trees, increasing bending moments and shear forces. Through the cleaving action of ice, crowns of trees are susceptible to break off.

4. Landslides and other slope processes convey standing and lying woody material towards the channel.

5. Avalanches are likely to incorporate and convey large volumes of woody material within the process perimeter.

Only a few exhaustive experimental results currently exist regarding woody material production and recruitment from different wood structures which are exposed to hydrodynamic impacts. Extensive experimental investigations have been carried out in order to study the hydraulic impact on vegetated riverbanks, e.g., the experiments carried out in the soil bioengineering test flume of the Vienna river (Rauch 2005). Furthermore, a series of 3D numerical simulations of vegetated Compound Channel Flows have been performed (Wilson et al. 2004). A second impact factor influencing woody material production is the wood structure itself. An analysis of recent flood events documented in the Province of Bolzano showed that wood vegetation in the river bed has a higher relative tendency to produce woody material (depending on wood stand volume) compared to wood vegetation on stream banks. In absolute terms, the amount of woody material recruited from the stream banks exceeded the volume recruited from the riverbank (Mazzorana et al. 2009). This fact can be attributed to the wood stand volume being on average larger on the bank slopes than in the river bed. In relation to the wood stand volume, wood vegetation located on the stream banks delivers more woody material due to lateral erosion phenomena than wood vegetation of the flood plain.

\subsection{Woody material entrainment and transport}

Theoretical models for woody material entrainment based on the balance of hydrodynamic $(F)$ and resistance forces $(R)$ on individual large woody material pieces have been developed by Braudrick et al. (1997) and Braudrick and Grant (2000). Assuming the shape of the woody debris pieces being cylindrical, and neglecting the influence of buoyancy, the hydrodynamic force can be expressed as follows (Haga et al. 2002):

$$
F=\frac{1}{2} C_{d} \rho\left(l h \sin \theta+A_{\text {sub }} \cos \theta\right) U^{2}
$$

where $C_{d}$, drag coefficient for the woody material element in water; $\rho$, density of the water; $l$, length of the woody material element; $h$, flow depth given by hydrodynamic simulations; $A_{\text {sub}}$, submerged area of the log perpendicular to length; $\theta$, angle of the element axis relative to the main flow direction; $U$, flow velocities given by hydrodynamic simulations as: $U=\sqrt{u^{2}+v^{2}}$.

The resistance forces can be expressed as follows:

$$
R=\left(g \sigma \frac{\pi l d^{2}}{4}-g \rho A_{\mathrm{sub}} l\right)(\mu \cos \alpha-\sin \alpha)
$$

where $d$, diameter of the woody material element; $\mu$, friction coefficient between the element and the channel bed; $\sigma$, density of the woody material element; $\alpha$, channel bed slope; $g$, gravity acceleration. 
Expressing the submerged area of the log perpendicular to its length can be defined as follows:

$$
A_{\text {sub }}=d^{2}\left\{\frac{1}{4} \cos ^{-1}\left(1-\frac{2 h}{d}\right)-\frac{1}{8} \sin \left[2 \cos ^{-1}\left(1-\frac{2 h}{d}\right)\right]\right\}
$$

Expressing the non-dimensional force $\Psi=\frac{F}{R}$ in terms of Eqs. 1 and 2, the following expression can be obtained (modified from Haga et al. 2002):

$$
\Psi=\frac{F}{R}=\frac{\frac{1}{2} C_{d} \rho\left(l h \sin \theta+A_{\text {sub }} \cos \theta\right) U^{2}}{\left(g \sigma \frac{\pi l d^{2}}{4}-g \rho A_{\text {sub }} l\right)(\mu \cos \alpha-\sin \alpha)}
$$

Analysing Eq. 4, the dynamics of a single woody material element with known dimensions can be described within a simplified scheme as follows (Haga et al. 2002):

Floating condition:

$$
\frac{h}{d} \geq 1
$$

Resting condition:

$$
\Psi=\frac{F}{R} \leq 1 \quad \text { and } \quad \frac{h}{d}<1
$$

Sliding or rolling condition:

$$
\Psi=\frac{F}{R}>1 \text { and } \frac{h}{d}<1
$$

Field observations are in good agreement with the earlier outlined theory. According to those evidences, the entrainment condition for smooth wood logs with an approximate cylindrical form is $1 \leq \frac{h}{d} \leq 1.2$. The ratio, $\frac{h}{d}$, increases for wood logs with branches up to 1.5 and for wood logs with root wads up to 1.7 .

The earlier outlined theoretical model does not consider the effects of morphodynamics. After Lange and Bezzola (2006), the entrainment is facilitated in the case of sediment transport due to the fact that the movable stream bed layer acts like a roller-bearing. In these conditions, the required flow depths, ceteris paribus, are 20-30\% lower compared to the case without sediment transport.

The procedure for evaluating woody material dynamics from a hazard-related perspective relies on these theoretical principles and is described in the next section.

\section{Modelling approach}

This section provides a description of the developed modelling approach, which has been implemented into an ArcGIS-Esri ${ }^{\odot}$ environment. The criteria for the identification, localization and classification of the woody material recruitment areas are explained, followed by the procedure for woody material volume assessment. Subsequently, the relevant aspects of woody material transport dynamics, namely the entrainment, transport and deposition and remobilization processes, are thoroughly discussed and a computational scheme is proposed. Finally, an analysis procedure of interactions at critical stream configurations is introduced. 
3.1 Identification, localization and classification of woody material recruitment areas

Woody material recruitment areas are identified by the interpretation of aerial stereo images (photographs). According to the findings of Rauch (2005), an innovative ad hoc classification of the typologies of alluvial forests, lowland riparian forests and riverside woodland is proposed. The forested areas in the influence zone of the stream are classified into seven structural typologies according to their different behaviour when exposed to hydrodynamic loadings (Table 1). The classification criteria take into account the response of different vegetation and forest typologies to the hydraulic forces and impacts of flood processes. Figure 2 shows the interdependencies between woody material production (interpreted as "distance" from the point of origin in the coordinate system), the level of hydrodynamic impact forces (on the vertical axis), the position within the riparian zone (on the horizontal axis) and the vegetation structure (oblique axis). Table 1 also shows the potentially available volumes of woody material for each vegetation structure typology. In addition, Table 1 provides the description of the corresponding typical response mechanisms. The geomorphologic characteristics of the flood process areas have to be determined. These areas are classified as (1) stream bed, (2) stream bank and (3) process area of an extreme flood event.

The classification is made on the basis of digital elevation models, aerial photographs and a Lidar-based digital terrain model with a high spatial resolution. An output data set is obtained with the morphology of the stream influence zone.

\subsection{Assessment of the recruited woody material volume}

Three distinct computational procedures for the assessment of woody material recruitment volumes are presented for: the recruitment from (1) hill slopes, the recruitment from (2) tributaries, and (3) within the maximum extent of the flooded area.

Table 1 Structural classification of forested areas within the influence zone of the river (Blaschke et al. 2004)

\begin{tabular}{|c|c|c|c|c|c|}
\hline ID & $\begin{array}{l}\text { Structure } \\
\text { characteristics }\end{array}$ & $\begin{array}{l}\text { Assumed } \\
\text { response } \\
\text { characteristic }\end{array}$ & $\begin{array}{l}\text { Response in case } \\
\text { of flooding }\end{array}$ & $\begin{array}{l}\text { Stand volume } \\
\left(\mathrm{m}^{3} / \mathrm{ha}\right) \\
\text { Example: } \\
\text { Passirio } \\
\text { river }\end{array}$ & $\begin{array}{l}\text { Dead } \\
\text { wood } \\
\text { volume } \\
\left(\mathrm{m}^{3} / \mathrm{ha}\right)\end{array}$ \\
\hline 1 & $\begin{array}{l}\text { Young-growth forest, } \\
\text { dense }\end{array}$ & Flexible & Lie down, protect the soil & 40 & 5 \\
\hline 2 & $\begin{array}{l}\text { Young-growth forest, } \\
\text { fragmentary }\end{array}$ & Flexible & $\begin{array}{l}\text { Lie down, increased turbulences, } \\
\text { rough, protect the soil }\end{array}$ & 20 & 3 \\
\hline 3 & $\begin{array}{l}\text { Multilayered } \\
\text { structure, dense }\end{array}$ & $\begin{array}{l}\text { Flexible and } \\
\text { inflexible }\end{array}$ & $\begin{array}{l}\text { Reduces flow velocity, rough, } \\
\text { protect the soil }\end{array}$ & 240 & 25 \\
\hline 4 & $\begin{array}{l}\text { Even aged population, } \\
\text { dense }\end{array}$ & Inflexible & $\begin{array}{l}\text { Reduces flow velocity, protect the } \\
\text { soil }\end{array}$ & 400 & 40.2 \\
\hline 5 & $\begin{array}{l}\text { Multilayered } \\
\text { structure, } \\
\text { fragmentary }\end{array}$ & $\begin{array}{l}\text { Flexible and } \\
\text { inflexible }\end{array}$ & $\begin{array}{l}\text { Different velocities, turbulences, } \\
\text { rough }\end{array}$ & 120 & 18 \\
\hline 6 & $\begin{array}{l}\text { Even aged population, } \\
\text { fragmentary }\end{array}$ & Inflexible & $\begin{array}{l}\text { Different velocities, turbulences, } \\
\text { unruffled }\end{array}$ & 200 & 24 \\
\hline 7 & $\begin{array}{l}\text { Old growth, very } \\
\text { patched }\end{array}$ & Inflexible & $\begin{array}{l}\text { Elevated turbulences due to } \\
\text { circulation around, leachate }\end{array}$ & 150 & 20 \\
\hline
\end{tabular}




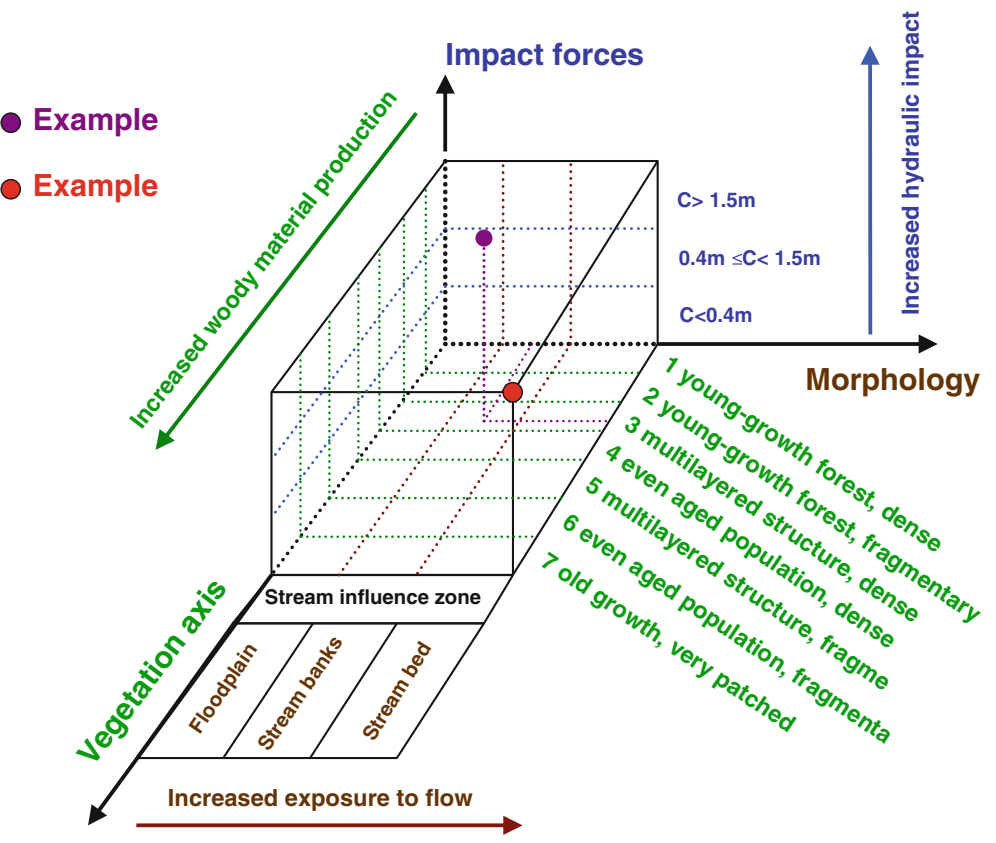

Fig. 2 Scheme for the assessment of the woody debris recruitment on regional scale

\subsubsection{Assessment of the recruitment volumes from hill slopes}

In this subsection, a procedure to assess the recruited woody material volumes from hill slopes is outlined. This assessment involves six steps:

Step 1 Determination of the perimeter of the flooded areas of the considered extreme event from flow depth or velocity raster data sets. The flow depth or velocity data sets corresponding to the different time steps are given as output files of the hydrodynamic simulations performed with the 2D numerical model Sobek Rural (WL/Delft Hydraulics 2004). These raster data sets are overlaid in order to derive the perimeter identifying the maximum extent of the flood (see Fig. 3 for details).

Step 2 A screening for the availability of wood-covered areas outside of the maximum flood boundaries. These wood-covered areas within a buffer width are categorised as active wood buffer (AWB) areas. This buffer width corresponds either to the potential tree height derived from the forest typology map (Klosterhuber et al. 2007) or to the real tree height retrieved from the Lidar-based digital surface model and the digital terrain model (Mazzorana et al. 2009). The difference between the surface model and the terrain model can give hints about the reference tree height and therefore about the width of the active wood buffer.

Step 3 Identification of the recruitment wood buffer strips. Inside the delimitation polygon of the maximum extent flood area, buffer strips for the wood volumes, potentially recruited form the AWB areas, are identified in direct proximity to the AWB areas (see Fig. 3 for details). The width of these strips is half of the tree height of the adjacent AWB area and corresponds to the area of possible location of the centre of gravity of the recruited wood logs. 


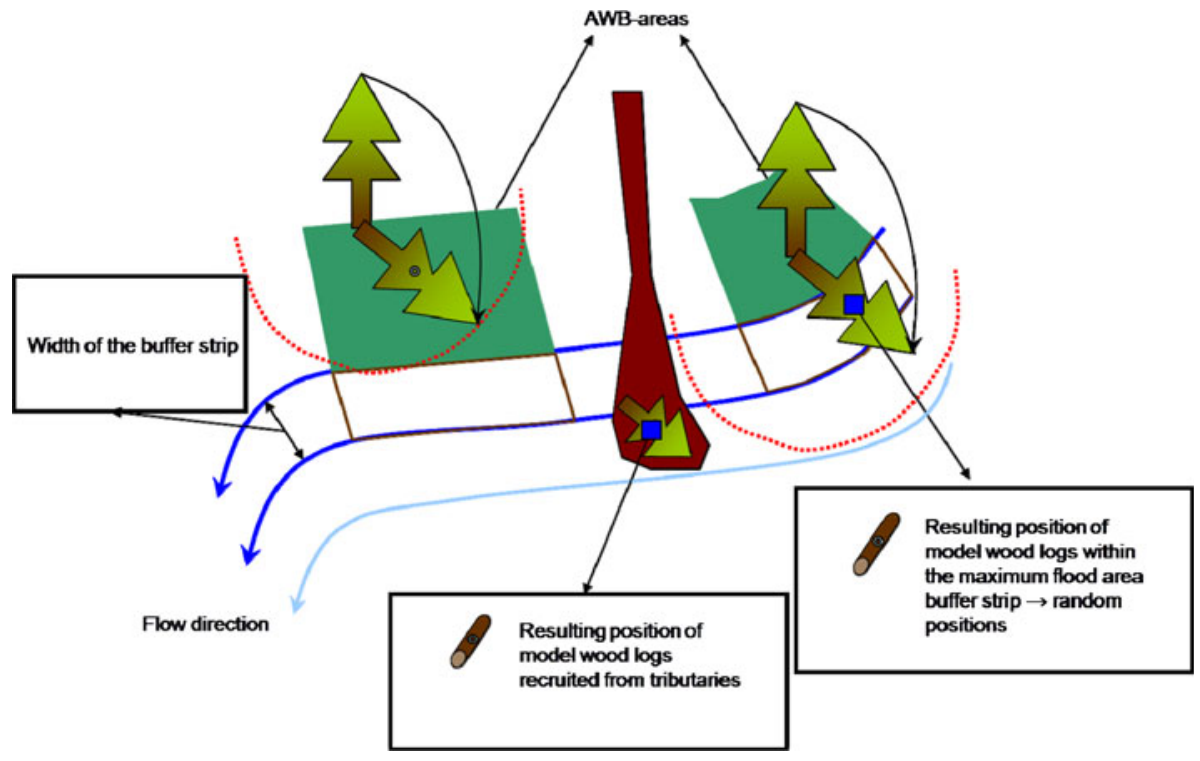

Fig. 3 Determination of the recruitment strips within the maximum extent buffer areas

Step 4 Computation of the length of the contact boundary between the AWB areas and the buffer strips (identified in step 3). The user has to define the volume of recruited woody material per unit length of contact boundary for each AWB area. An estimation of recruitment volume scenarios is made on the basis of experimental data provided by inventories (Rickli and Bucher 2006). It should be noted that uncertainty is not negligible without detailed forest inventories and a precise estimation of dead wood volumes and forest stand stability conditions of the forest population. It is recommended to define a plurality of scenarios of recruitment volumes per unit length.

Step 5 Specification of the dimension and number of the model wood logs. In this step, the dimensions of the "model wood log" (diameter and log length) are specified and the determination of the recruited number of model wood logs for each strip is straightforward, once known the volumes from the recruitment scenarios defined in the previous step. The position of the centre of gravity of the "model wood logs" is either chosen at random (see Fig. 3) or assessed by field investigations.

Step 6 Determination of the starting position of the "model wood logs". The volume of each recruited "model wood $\log$ " is assigned to the corresponding flow cell depending on the position of its centre of gravity (compare Fig. 3).

\subsubsection{Assessment of the recruitment volumes from tributaries}

This assessment involves the following two steps:

Step 1 The recruitment scenarios of wood material volumes from the tributaries can be reliably defined only if a detailed documentation exists for events. If information 
is missing, possible scenarios of recruited woody material volumes can be defined on the basis of empirical equations (Rickenmann 1997).

Step 2 The number of "model wood logs" is calculated. Again the problem arises of the positioning of the "model wood logs" within the maximum extent flood area. In the case of accurate event documentations, the "model wood logs" can be placed within the geo-referenced depositional areas (see Fig. 3). Otherwise, engineering judgement is required to position the "model wood logs" by choosing, e.g., probable deposition sites.

\subsubsection{Assessment of the recruitment volumes within the flooded area}

Forests of different wood typologies produce determined amounts of dead wood ready for transport depending on the current stage in their "life cycle". During the flood event itself, additional dead wood is produced as a consequence of either direct hydrodynamic impact on trees or destabilization of the trees' anchorage through erosion phenomena (root wad scouring).

The vegetation structures are mapped and the morphology of the riverbank is overlaid with the outputs of the respective flood simulation. A woody material recruitment indicator is computed based on an impact-response assessment approach, which considers either the morphological characteristics or the flood intensity. This impact-response assessment approach has been developed on the basis of the findings of Rauch (2005) and Hübl et al. (2008). Experimental studies should further investigate the interplay of the following key factors: (1) Hydrodynamic impact: The hydrodynamic impact acts, on the one hand, through static and dynamic pressure forces on wood vegetation and, on the other hand, by yielding stress on the soil, weakening the root-soil anchorages. (2) Wood stand volume: A positive correlation between the recruited woody material volume and the wood stand volume is postulated. Average wood stand volume estimations for different wood stand structures are reported in Table 1. (3) Wood vegetation resistance-resilience: The influence of the aforementioned key factors cannot be understood and quantitatively estimated without assessing wood vegetation resistance-resilience mechanisms. These depend on both wood structural and species-specific characteristics. For the necessary accuracy level, the analysis is limited to the first type of characteristics underlining that resistance-resilience against hydrodynamic impact depends significantly on the flexibility of the wood and on recovery capacity. In addition, a very flexible vegetation structure protects the soil from erosion, while inflexible-old growth-population structures are weakened by erosion mechanisms and are also unstable due to an unfavourable slenderness $(h / d)$ ratio. These interaction phenomena are described in Table 1.

The assessment scheme is shown in Fig. 2, where the energy indicator $C_{i, j}$ describes hydraulic impact on vegetation structures (see Eq. 8). The energy indicator is composed of a hydrostatic and a hydrodynamic pressure term and it is calculated as follows (Egli 2008, Holub and Hübl 2008):

$$
Q_{i, j}=\rho g h_{i, j}+\frac{c_{d} \rho U_{i, j}^{2}}{2}
$$

where $i, j$, cell indices; $h_{i, j}$, flow depth $[\mathrm{m}] ; U_{i, j}$, flow velocity $[\mathrm{m} / \mathrm{s}] ; Q_{i, j}$, pressure load; $c_{d}$, drag coefficient; $\rho$, density of the water.

Dividing both terms on the right hand side of Eq. 8a by $\rho g$ and assuming $c_{d} \approx 1$, we obtain the specific load: 


$$
C_{i, j}=\frac{Q_{i, j}}{\rho g}=h_{i, j}+\frac{U_{i, j}^{2}}{2 g}
$$

The flow velocity is calculated from the velocities in direction $x$ and $y$ :

$$
U_{i, j}=\sqrt{u_{x_{i, j}}^{2}+u_{y_{i, j}}^{2}}
$$

where $u_{x_{i, j}}$, flow velocity in $x$ direction $(\mathrm{m} / \mathrm{s}) ; u_{y_{i, j}}$, flow velocity in $y$ direction $(\mathrm{m} / \mathrm{s})$.

By a qualitative analysis of documented flood events (Mazzorana et al. 2009), the following assessment procedure for woody material recruitment could be established (see Fig. 4): (1) Identification and spatial delimitation of possible woody material recruitment areas, (2) assignment of these recruitment areas to the appropriate river morphology categories (e.g., stream bed, river banks, flood plain), (3) determination of the wood structure characteristics and definition of the respective structure typologies (see Table 1), (4) calculation of an indicator describing the hydraulic impact (Eq. 8a, 8b), (5) estimation of the recruitment volumes (recruited wood volume per hectare/stand volume per hectare), here referred to as woody material recruitment indicator (SVI) on the basis of the scheme shown in Fig. 4 and (6) quantification (see Eq. 10) of the absolute volume of recruited woody material $\left(V_{\mathrm{SH}}\right)$.

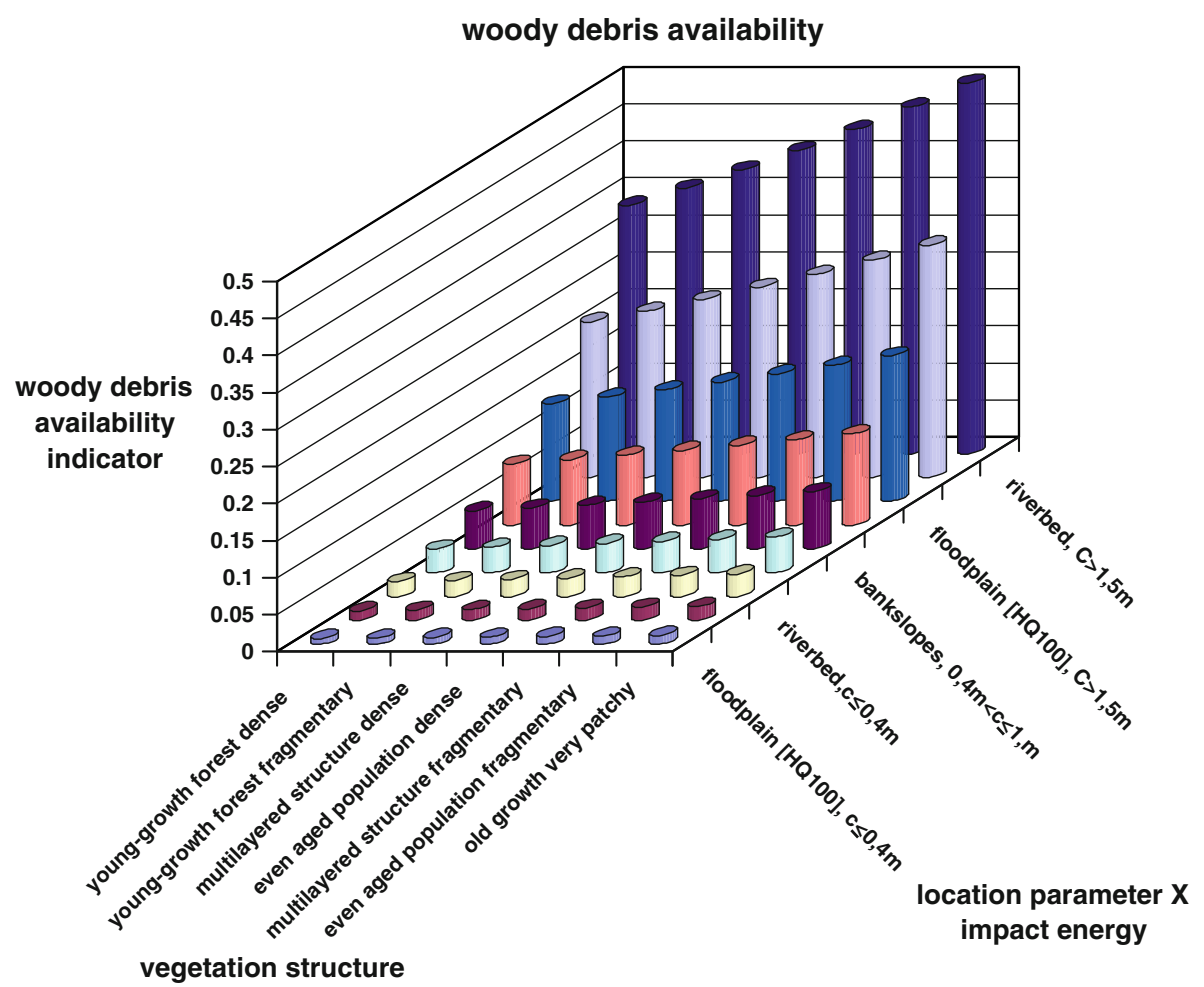

Fig. 4 Decision matrix for the quantification of the woody debris availability on a regional scale. Expertbased estimation of the woody material availability indicator 
The parameter of the absolute volume of recruited woody material indicates the maximum volume of woody material that could be ripped at a given location by the flood process.

Finally, the recruited woody material volume for each cell is calculated as

$$
V_{\mathrm{SH}, i, j}=\mathrm{SVI}_{i, j} \cdot V_{\text {cell }, i, j}
$$

Since the wood stand volume is given as a parameter showing values per hectares, Eq. 11 is used to calculate the woody material volume.

$$
V_{\mathrm{SH}, i, j}=\mathrm{SVI}_{i, j} \cdot\left(\frac{A_{i, j}}{10000}\right) \cdot V_{\mathrm{ha}}
$$

where $V_{\text {cell, } i, j}$, wood stand volume for the cell $i, j ; V_{\text {ha }}$, wood stand volume referred to an area of $1 \mathrm{ha} ; A_{i, j}$, area of the cell $i, j$ in $\mathrm{m}^{2}$.

The resulting output from this step is the calculated maximal volume of woody material that could be ripped out from each cell by the flood.

The estimations of the recruited wood volumes per hectare and the quantification of the absolute volume of recruited woody material (step 5 and 6 of the earlier outlined procedure, respectively) can be computed also following a slightly modified procedure, which explicitly accounts for the subdivision of the flood duration in time steps $\Delta t$. Two essential requirements are:

a. Knowledge about the dead wood material available in each cell at time $t^{0}$.

b. Knowledge about the amount of greenwood, which, through either stem breakage or "uprooting" (and toppling) due to erosion, becomes dead wood ready for transport at the beginning of the successive time step.

Consequently, maximum estimated dead wood amounts for different forest typologies and predictions of the dead wood amounts produced in a given time step are required. Plausible values of dead wood volumes for different wood typologies range from 3 to $40.2 \mathrm{~m}^{3} /$ ha. In Table 1, estimations of possible dead wood volumes for different wood typologies are reported.

The prediction of the dead wood volumes, which are produced in a given time step in a determined forest typology exposed to determined hydrodynamic impacts and to determined river bed dynamics, is conduced with the following linear relationship:

$$
V_{\mathrm{DW}, i, j}^{\Delta t}=k \cdot \mathrm{SVI}_{i, j}^{t} \cdot V_{\mathrm{GW}, i, j}^{t} \cdot \Delta t
$$

where $V_{\mathrm{DW}, i, j}^{\Delta t}$, dead wood produced within the time step $\Delta t$ in the cell $i, j ; \mathrm{SVI}_{i, j}^{t}$, response class $[1 / \mathrm{s}]$ (determined in full analogy to the first theory) for cell $i, j ; V_{\mathrm{GW}, i, j}^{t}$, living wood volume in the cell at time step $t\left[\mathrm{~m}^{3}\right]$ in cell $i, j ; \Delta t$, time step (s); $k$, empirical constant, to be assessed on the basis observed extreme floods.

The amount of living wood at time step $t+1$ is computed as follows:

$$
V_{\mathrm{GW}, i, j}^{t+1}=V_{\mathrm{GW}, i, j}^{t}-V_{\mathrm{DW}, i, j}^{\Delta t}
$$

It should be noted that the influence of morphodynamics is not considered in its full complexity in this approach (e.g., no mobile bed or shear stress computations are performed). Morphodynamics are considered indirectly and in a simplified way in the estimation procedure of the woody material recruitment indicator $\left(\mathrm{SVI}_{i, j}^{t}\right)$ by assigning a location attribute (i.e., stream bed, stream bank or flood plain) to each cell (compare Figs. 2, 4). 


\subsection{Woody material transport dynamics}

Having defined and quantified the recruitment areas, the transport of material from these areas to the defined weak points or critical river locations and cross sections can be modelled. The modelling procedure is able to consider two different approaches for modelling the transport of woody material. If the main objective is the estimation of the pathways and the possible deposition zones, the transport of woody material is calculated on a cell-by-cell basis. This approach allows analysing the transportation and deposition dynamics either on a regional level or on a more detailed level. With this modelling approach, only one time step of the hydraulic modelling results can be considered. If the main objective is to study the interactions of transported woody material with obstacles such as bridges, the transport of woody material is calculated following an object-oriented approach. This approach allows for a consideration of more time steps of the hydraulic modelling and the deposition of woody material on sand banks during the falling limb of a flood hydrograph. In such a way, it is possible to keep track of the positions of the woody material elements from time step to time step.

The basics for the calculation of the transport dynamics are the same in the two approaches and are based on the following simplified model. This model delineates the possible pathways for woody material transport and computes for each of them the entrainment and transport conditions based on the theory outlined in Sect. 2.2 and on the following method. The input data are the raster results from a hydrodynamic $2 \mathrm{D}$ simulation of the design event ( 1 in 300 years return period) for water depths $h_{i, j}$ and flow velocities in $x$ and $y$ direction, $u_{x_{i, j}}$ and $u_{y_{i, j}}$. These rasters represent the state of the hydraulic simulation of different time steps. For each cell in the affected flood area, the flow direction is calculated according to the respective flow velocity in $x$ and $y$ directions, and given this flow direction, the source cell is moved until it is fitted into the next two neighbouring cells. The amount of woody material arriving from the source cell is divided into two portions according to the overlapping area of the moved source cell with the two neighbouring cells (Fig. 5). The particular portion of each subsequent cell is added, giving the total amount in this cell. The volumes passed through each cell are cumulated, and a grid data set of the woody material volume passed through each cell of the river influence zone is produced.

Fig. 5 Determination of the following cells $(A$ and $B)$ and their particular portion of the woody material from the source cell to receive

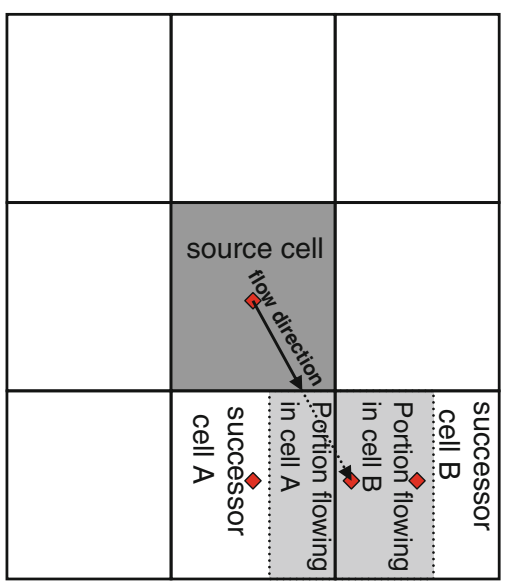


This approach is based on a further simplification of Eqs. 1 and 2 in order to precisely determine the woody material transport analysis conducted on a hazard index level (Petraschek and Kienholz 2003). Assuming that the woody material elements are positioned perpendicular to the flow direction $\left(\theta=90^{\circ}\right)$ and that the length of each element is expressed as a multiple of its diameter, $l=n d$, with $n \geq 1$; Eq. 14 is obtained from Eq. 1 .

$$
F=\frac{1}{2} C_{d} \cdot \rho \cdot k \cdot d \cdot h_{i, j} \cdot U_{i, j}^{2}
$$

Taking the hypothesis that the density of the wood element can be expressed as $\sigma=n \cdot \rho$ with $n \cong 1$ and that the local slope angle at the wood element locations is very small, $\alpha \cong 0^{\circ}$, Eq. 2 can be rewritten as:

$$
R=\mu \rho g l\left(\frac{\pi d^{2}}{4}-A_{\text {sub }}\right)=g \rho k d \mu\left(\frac{\pi d^{2}}{4}-A_{\text {sub }}\right)
$$

Based on Eqs. 3 and 4 can be rewritten as:

$$
\begin{aligned}
\Psi & =\frac{F}{R}=\frac{\frac{1}{2} C_{d} \rho k d h_{i, j} U_{i, j}^{2}}{g \rho k d \mu\left(\frac{\pi d^{2}}{4}-A_{\mathrm{sub}}\right)}=\frac{\frac{1}{2} C_{d} h_{i, j} U_{i, j}^{2}}{g \mu\left(\frac{\pi d^{2}}{4}-A_{\mathrm{sub}}\right)} \\
& =\frac{2 C_{d} h_{i, j} U_{i, j}^{2}}{g \mu d^{2}\left\{\pi-\cos ^{-1}\left(1-\frac{2 h_{i, j}}{d}\right)+\frac{1}{2} \sin \left[2 \cos ^{-1}\left(1-\frac{2 h_{i, j}}{d}\right)\right]\right\}} .
\end{aligned}
$$

Subsequently, the velocity corresponding to $\Psi=\frac{F}{R}=1$, here named as threshold velocity, $U_{\text {lim }}$, for the movement of the wood element, is determined accordingly by

$$
\begin{aligned}
U_{\lim _{i, j}} & =\sqrt{\frac{2 g \mu}{C_{d} h_{i, j}}\left(\frac{\pi d^{2}}{4}-A_{\text {sub }}\right)} \\
& =\sqrt{\frac{g \mu d^{2}}{2 C_{d} h}\left\{\pi-\cos ^{-1}\left(1-\frac{2 h_{i, j}}{d}\right)+\frac{1}{2} \sin \left[2 \cos ^{-1}\left(1-\frac{2 h_{i, j}}{d}\right)\right]\right\}}
\end{aligned}
$$

Given these results and the conditions stated for expressions 5, 6 and 7, the cell-based transport inhibition parameter is defined as follows:

Case 1: If $h_{i, j} \geq d$, the wood material element is floating and the associated specific transport inhibition parameter is $c_{i, j}^{*}=0$.

Case 2: If $h_{i, j}<d$ and

$$
\begin{aligned}
& 0<U_{i, j} \leq \sqrt{\frac{g \mu_{i, j} d^{2}}{2 C_{d} h_{i, j}}\left\{\pi-\cos ^{-1}\left(1-\frac{2 h_{i, j}}{d}\right)+\frac{1}{2} \sin \left[2 \cos ^{-1}\left(1-\frac{2 h_{i, j}}{d}\right)\right]\right\}} \text { or } \\
& 0<U_{i, j} \leq U_{\lim _{i, j}}
\end{aligned}
$$

a condition of resting is imposed to the wood material element. The associated specific transport inhibition parameters $c_{i, j}^{*}=1$.

Case 3: If $h_{i, j}<d$ and $U_{i, j}>U_{\lim _{i, j}}$ a condition of either sliding or rolling is imposed to the wood material element. The value of the associated transport inhibition parameter is expressed by:

$$
c_{i, j}^{*}=1-\frac{F_{i, j}}{F_{i, j}^{*}}=1-\frac{\frac{1}{2} C_{d} \rho k d h_{i, j} U_{i, j}^{2}}{\frac{1}{2} C_{d} \rho k d^{2} U_{i, j}^{2}}=1-\frac{h_{i, j}}{d}
$$

where $c_{i, j}^{*}$, transport inhibition parameter of the cell $i, j$ (non-dimensional). 
Observations noted by Diehl (1997) and Ng and Richardson (2001) indicate that woody material in ideal conditions is transported on the surface as individual pieces aligned with the flow and travelling at about the same velocity as the average water velocity at the surface.

Using the average velocity instead of the surface velocity as reference velocity for the moving woody material for a wide range of flow conditions, velocity along the transport trajectory for each moving woody material model log is estimated as follows:

$$
U_{\text {wood }_{i, j}}=\left(1-c_{i, j}^{*}\right) U_{i, j}
$$

where $U_{\text {wood }_{i, j}}$, velocity of a wood $\log$ in the cell $i, j$.

An analysis of the expression for the wood log velocity (Eq. 19) reveals that if the transport inhibition parameter tends to 1 , coherently with resting or deposition conditions the velocity of the wood log tends to 0 , whereas if the transport inhibition parameter tends to 0 , the velocity of the wood $\log$ tends to $U_{i, j}$. Through this method, it is possible to describe woody material transport pathways under unsteady flow conditions. A deposited woody material log can be remobilised in a successive time step under changed flow depth and flow velocity conditions.

\subsection{Potential hazard impacts at critical stream configurations}

The object-oriented approach for modelling the woody material transport dynamics as outlined in chapter 3.3 allows for an assessment of potential hazard impacts at critical stream configurations. This approach considers the model wood logs as points, representing the centre points of the model wood log. Each single object has information about $\log$ diameter, log length, diameter of root wads and impact-resistance characteristics as outlined in Fig. 2. The flowing of the model wood logs is computed following the procedure as proposed in Chap. 3.3.

A simplified assessment procedure for entrapment and deposition phenomena at special obstacles (e.g., bridges) is outlined. In Fig. 6a, a stream section with a crossing bridge is shown. Along the flow path, woody material can potentially interact with: (1) the superstructure of the bridge, (2) a single bridge pier and/or (3) two or more bridge piers.

Two types of obstacles are defined in order to model the interaction between these obstacles and the floating woody material:

In-stream-obstacles Obstacles standing in the water such as piers or abutments. On these obstacles, transported logs can get entrapped upon collision at any stage of the flood.

Crossing obstacles Obstacles crossing the stream at a given height on which the logs can get entrapped with their root plate when the flow depth approaches the object's height i.e., lower chord of the superstructure of a bridge, see Fig. 6a.

Within the computational procedure, these obstacles are represented by polygonal objects. The following attributes are required to comprehensively describe these obstacles:

1. Retention probability ( $p_{\text {ret }}$ ): Probability for each colliding log to get entrapped at the considered obstacle. This gives the expert the possibility to consider the geometry (e.g., profile) of an obstacle (e.g., inappropriately shaped piers) and estimate a proper retention probability 
(a) Cross-sectional view

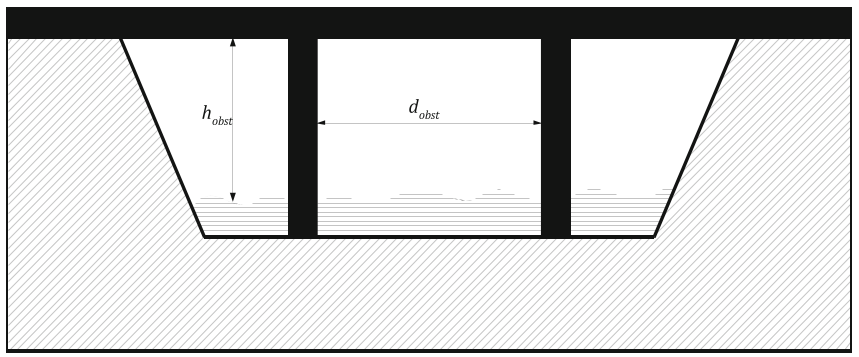

(b)

top view

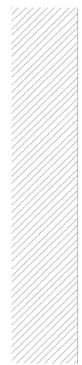



(c)

top view

Fig. 6 a Example of a bridge as an obstacle consisting of two piers as in-stream-obstacles and the superstructure as a crossing obstacle $d_{\text {obst }}$ indicates the minimum distance between the two piers and $h_{\text {obst }}$ the height of the superstructure. b Example of a collision with an in-stream-object. The flow path intersects the shape of a pier. In this case, the floating log is entrapped at the first intersection point between the flow path and the shape of the pier. c Example of a woody material object floating between two piers of a bridge. The flow path does not cross any of the piers; however, the length $\left(l_{\log }\right)$ exceeds the minimum distance between the two pillars $\left(d_{\text {obst }}\right)$ and the possibility of entrapment occurs

2. Obstacle height $\left(h_{\text {obst }}\right)$ : Height of the lower chord of a crossing obstacle above the initial water level. The obstacle type is defined using the obstacle height (Fig. 6a). In case the obstacle height equals zero, an object is treated as in-stream-obstacle, otherwise the object is handled as a crossing obstacle

A collision with an obstacle occurs when the flow path of a woody material log intersects an obstacle. If it is a crossing obstacle, the flow depth needs to reach a critical value. Above this value, the root plate can contact the lower chord of the obstacle. Depending on the retention probability of the obstacle, specified by expert judgement, the woody material logs may either be entrapped or flushed through (see Fig. 6b).

If an object is floating between two in-stream-obstacles, e.g., two piers, it is checked whether the length of the log exceeds the shortest distance $\left(d_{\text {obst }}\right)$ between the two piers. If so, a spanning blockage can occur, provided that the log is unfavourably oriented. The corresponding probability $\left(p_{\text {ent }}\right)$ is estimated through expert judgement.

The entrapped wood logs occlude part of the available flow section and become a part of the obstacle for wood logs subsequently approaching the critical configuration (see Fig. 6c). 


\section{Study site and test application}

The Passer/Passirio River in the Autonomous Province of Bolzano-South Tyrol, Italy was chosen as test site for the application of the procedure described in the previous sections (Fig. 7). The Passer/Passirio River drains a catchment area of approximately $415 \mathrm{~km}^{2}$ and opens to the receiving watercourse Etsch/Adige River near the city of Meran/Merano, Italy. The study area comprises the river bed and the extent of the simulated flooded areas of the Passer/Passirio River during a flood event with a return period of 1 in 300 years. A relevant volume of woody material arriving from the upper parts of the catchment is entrapped at the open check dam located in the upstream river reach. The upstream boundary of the simulation area is located at this open check dam near the community of St. Leonhard in Passeier/S. Leonardo in Passiria. A high-magnitude flash flood occurred in the Passer/ Passirio River in 1987 (Fig. 8), resulting in severe damage to regionally important bridges and roads. The downstream boundaries were defined near the locality of Saltaus/Saltusio at a bridge location (Fig. 7b). The cumulative volume of the transported woody material was calculated here. Within the studied river reach, the channel bed is characterised by twelve tributaries with relevant input of woody material. The material supplied by the tributaries was considered in this study. Figure $7 \mathrm{c}$ summarises the extent of the system.

The woody material volumes delivered by the tributaries were assessed and quantified by analysing recent debris flow events. Table 2 shows the assumed values for the available woody material inputs. The interceptors (e.g., bridges and check dams) within the river
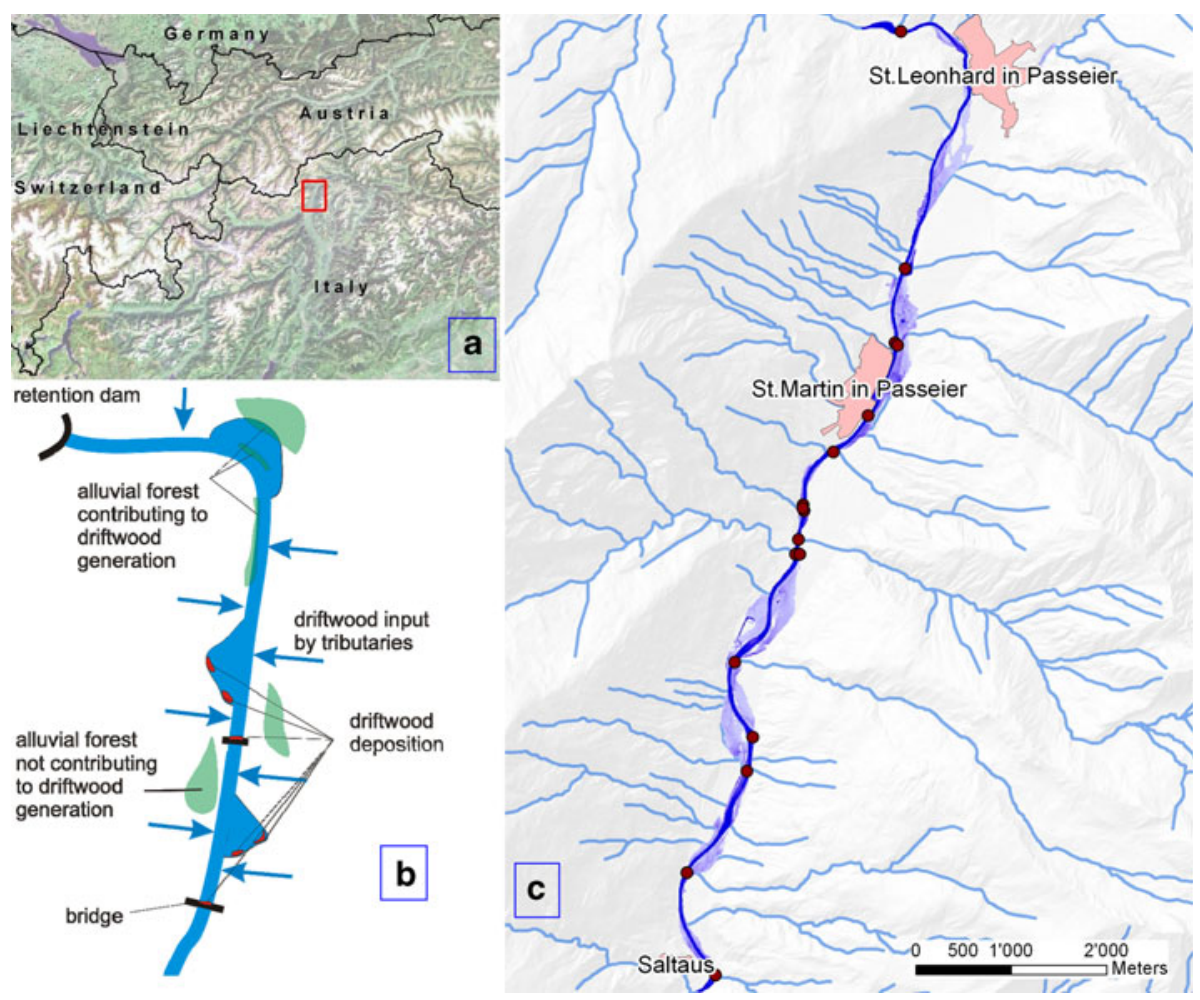

Fig. 7 a Localization, b system description and c extent and delimitation of the study area 


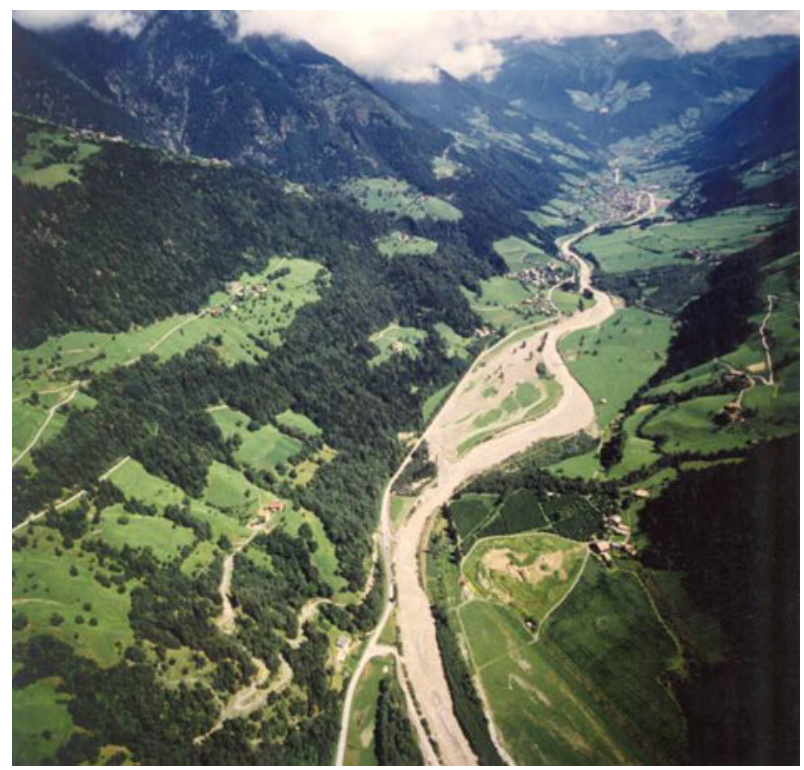

Fig. 8 An aerial image of the study area after the flood event in 1987

influence zones were geo-referenced. For each of these critical configurations, the geometrical characteristics were assessed and a retention probability was assumed. This retention factor accounted for the woody material volumes retained by the obstacle. The simulation procedure was repeated with and without consideration of these weak points.

The inflow hydrograph (return period of 1 in 300 years) at the upstream boundaries of the study area was calculated with the GIS-based hydrologic modelling system BaSIn 30 (AIDI 2005). The flood propagation computations were carried out with the hydrodynamic simulation model SOBEK Rural (WL/Delft Hydraulics 2004), which is capable of computing the full numerical solution of the shallow water equations. For a hazard indication analysis level, a pure 2D overland flow simulation was performed. Outputs included the flow depths and the flow velocities in $x$ and $y$ direction for the different time steps (e.g., $30 \mathrm{~min}$ for computations at the hazard index level). The flood simulation was performed on the basis of a digital elevation model delineated by airborne laser scanning technique with an original resolution of $2.5 \mathrm{~m}$, upscaled to a resolution of $10 \mathrm{~m}$.

For the calculation of the woody material transport dynamics, a reference diameter of the wood elements of $d=0.3 \mathrm{~m}$ was assumed. A drag coefficient of $C_{d}=0.8$ and a friction coefficient of $\mu=1.0$ were used during the sets of calculation. For an analysis conducted at a hazard index level, a value of $1.4 \times 10^{-4}$ was chosen for the parameter $k_{1}$ in Eq. 12. A detailed analysis of transport dynamics at critical bridge locations has been carried out.

\section{Simulation results}

The application of the method outlined in Sect. 3.1 resulted in a map of the vegetation structures, a map of the morphological characteristics of the river influence zone and 
Table 2 Assumed values for the input of woody debris from the tributaries

\begin{tabular}{|c|c|c|c|}
\hline $\begin{array}{l}\text { Torrent } \\
\text { ID }\end{array}$ & Name of torrent & $\begin{array}{l}\text { Woody debris } \\
\text { volume }\left(\mathrm{m}^{3}\right)\end{array}$ & Notes \\
\hline G & Passer/Passirio & 10 & $\begin{array}{l}\text { Initial condition: woody material } \\
\text { passing } \\
\text { through the retention dam }\end{array}$ \\
\hline G.255 & Keltalbach/Rio Lega & 20 & Torrent with debris flow processes \\
\hline G.235 & Talbach/Rio di Valle & 2 & Torrent with debris flow processes \\
\hline G.230 & Fartleisbach/Rio dell'Avas & 5 & Torrent with debris flow processes \\
\hline G.220 & Dorfbach/Rio Dorf & 5 & Torrent with debris flow processes \\
\hline G.205 & $\begin{array}{l}\text { Schoenbichlbach (Kellerbach)/Rio di } \\
\text { Belcolle }\end{array}$ & 5 & Torrent with debris flow processes \\
\hline \multirow[t]{3}{*}{ G.195 } & $\begin{array}{l}\text { Heimatscheintal/Rio del Masso dei } \\
\text { Tovi }\end{array}$ & 5 & Torrent with debris flow processes \\
\hline & & 100 & $\begin{array}{l}\text { Lumbryhood in the neighbourhood } \\
\text { upstream } \\
\text { of the confluence of the } \\
\text { Heimatscheintal/ } \\
\text { Rio del Masso dei Tovi torrent }\end{array}$ \\
\hline & & 200 & $\begin{array}{l}\text { Lumbryhood in the neighbourhood } \\
\text { upstream } \\
\text { of the confluence of the } \\
\text { Heimatscheintal/ } \\
\text { Rio del Masso dei Tovi torrent }\end{array}$ \\
\hline G.190 & Grafeisbach/Rio Graves & 20 & Torrent with debris flow processes \\
\hline \multirow[t]{2}{*}{ G.185 } & Kalbenbach/Rio della Clava & 10 & Torrent with debris flow processes \\
\hline & & 40 & $\begin{array}{l}\text { Lumbryhood in the neighbourhood } \\
\text { downstream } \\
\text { of Grafeisbach/Rio Graves } \\
\text { torrent }\end{array}$ \\
\hline \multirow[t]{2}{*}{ G.175 } & $\begin{array}{l}\text { Prantlbach-Brandwaldbach/Rio } \\
\text { Prantola }\end{array}$ & 30 & Torrent with debris flow processes \\
\hline & & 20 & $\begin{array}{l}\text { Lumbryhood in the neighbourhood } \\
\text { upstream } \\
\text { of the confluence of the G.155 } \\
\text { torrent }\end{array}$ \\
\hline G.145 & Widnerbach/Rio di Videna & 2 & Torrent with debris flow processes \\
\hline G.120 & Badbach/Rio di Bagno & 4 & Torrent with debris flow processes \\
\hline G.110 & Mainlechnerbach/Rio di Main & 20 & Torrent with debris flow processes \\
\hline
\end{tabular}

computed maximal volumes of recruited woody material within the considered system. Figure 9a shows an extract of the mapped vegetation structures within a channel section, indicating that a substantial part of the river influence zone in the study area is covered by vegetation. Thus, the recruitment of considerable amount of woody material is plausible. In Fig. 9b, the mapped geomorphologic classification of the river influence zone is shown, and in Fig. 10a, detail of the cell-by-cell simulation results is provided. The results show an increased concentration of woody material transport in the centre of the streamline. Additionally, the potential deposition areas of woody material are given; deposition primarily took place in flooded areas with low flow depths or low flow velocities outside of the river channel. Within the river channel, deposition of woody material was modelled at 

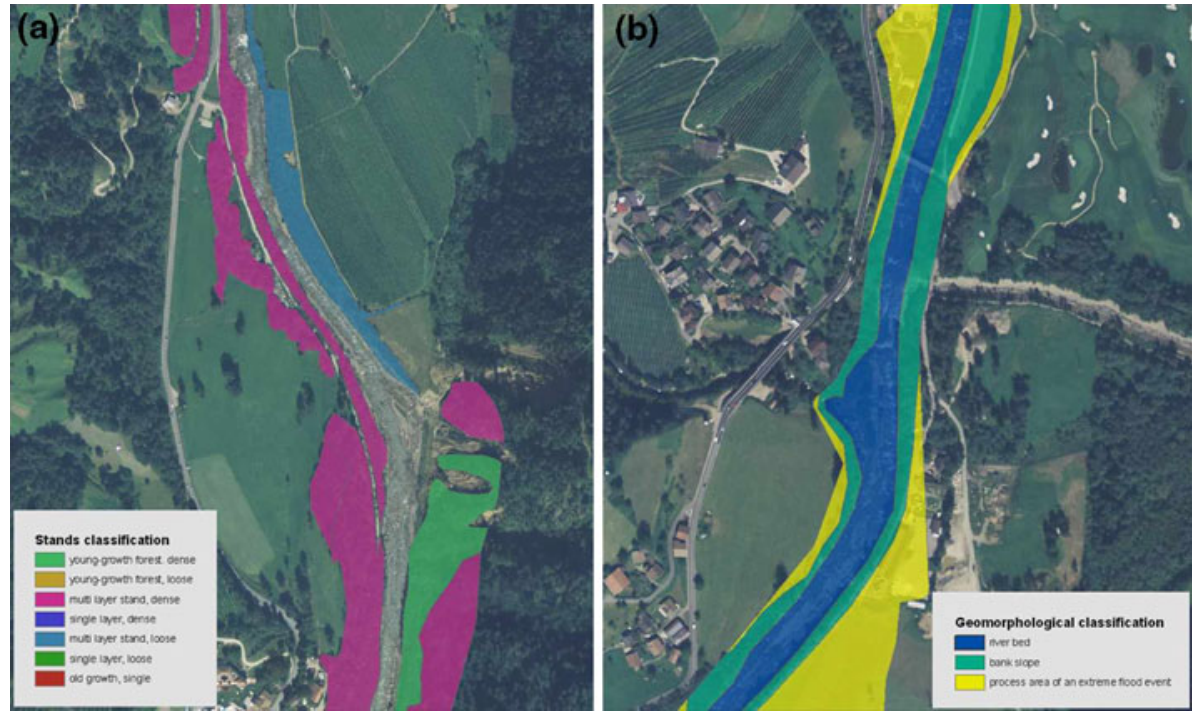

Fig. 9 a Extract of the mapped vegetation structure. b Extract of the mapped morphology of the river influence zones


Fig. 10 a Results of the cell-by-cell simulation of the woody material transportation and deposition volumes. The red colours show the volume of deposited driftwood, the blue colours show the volume of passing driftwood at each cell. The maximum values are calculated at the outflow cell. b Results of the object-oriented simulation of the deposition of woody material. The red dots show the centre of gravity of the deposited model wood logs

the waterside slopes, at the waterside of river bends and at calm loops. The modelled woody material deposition areas corresponded accurately with the mapped potential deposition areas. The maximum of transported woody material was calculated as $632 \mathrm{~m}^{3}$ in 
the last flow cell. This value indicates the maximum amount of transported woody material during a flood event with a reoccurrence period of 300 years at the outflow cell of the studied river reach. It corresponds with the dead wood volumes of 35 flooded hectares of different forest classes as shown in Table 1. This underlines that woody material transport and related phenomena are not negligible in the elaboration of the flood hazard zone map for the Passer/Passirio river. Additionally, the modelling results show the increase of transported driftwood along the river. At the upper reach of the river, small amounts of driftwood were computed; whereas downstream of each flooded wood stand with large dead wood volumes, the volume of transported driftwood increased. As expected, after a considerable deposition of driftwood, the volume of transported driftwood within the river channel decreased. Therefore, the modelling results lead to the identification of river reaches with significant driftwood transport. Since time dependency was not considered, the modelled design event had virtually an infinite duration, meaning that the entire amount of potentially removable wood stand volume was removed and mobilised. Thus, the computed woody material volumes represent the upper threshold in terms of potentially maximum values.

The cell-by-cell-based modelling procedure does not consider the rising and falling limb of the flood hydrograph as does the object-oriented modelling approach. Therefore, the results of the two approaches differ slightly. In general, the modelled deposition areas of both approaches are the same, but the computed deposition volumes differ slightly. Since the object-oriented approach considers different time steps of the flood process, it considers different process areas during the flood event. Therefore, the deposited volumes differ in situations where dead wood is re-mobilised after deposition due to the increase in the wetted perimeter or the increase in flow depth and/or velocities. The object-oriented approach outlines the track of each single model wood log and as such, the origin of the entrapped or deposited log could be assessed. Additionally, the consideration of more time steps of the flood simulation enables the tracking of the development of dead wood and the transport of the model wood logs in time. It was shown that most of the model wood logs flow repeatedly out from some of the flood forest areas. Only the flooding of a large area with the same wood stand characteristics and with high flood intensities led to a simultaneous burst of woody material into the river reach. The modelling procedure allows for the observation of these situations and the assessment of the consequences of the evolvement of $\log$ jams due to a simultaneous over-flooding. Figure $10 \mathrm{~b}$ shows the woody material deposition areas computed by the object-oriented approach. Each red dot represents one model wood log. The results of the investigation of woody material dynamics at the selected weak point (i.e., bridge location) are shown in Fig. 11. The computed interaction process of the model wood logs showed that the log jams increased constantly at obstacles during the modelled flood event. After the modelled flood process, the net volume of the log jam at the selected bridge between Oberpsairer and Möre was around $3 \mathrm{~m}^{3}$. Figure 11 shows the computed log jam at the bridge, and Fig. 12 show the bridge destroyed by the flood event in 1987 . The picture does not allow reconstructing the total amount of driftwood entrapped at the bridge, as the bridge was over-flooded after the break of the left pillar and the entrapped woody material was transported away. However, Fig. 11 confirms the entrapment of driftwood with this obstacle. The procedure for modelling the interaction of the model wood logs with critical stream configurations calculates the volume of retained driftwood at every obstacle. The retention volume depends on the characteristics of the obstacle itself, and trapped driftwood necessarily reduces the volume which is transported downstream of the obstacle. This method allows for the identification of the systematically most relevant weak points in the system. 

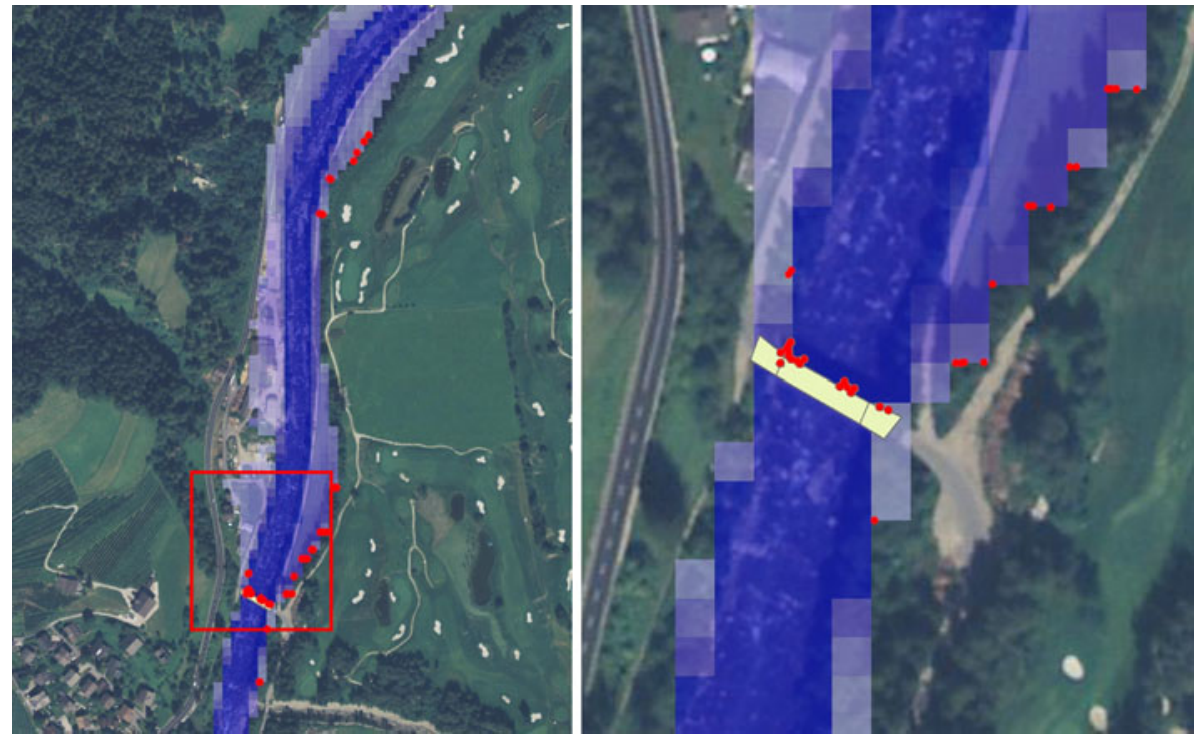

Fig. 11 Entrapment at a critical configuration. The graphic at the right side shows the entrapped driftwood on a more detailed scale

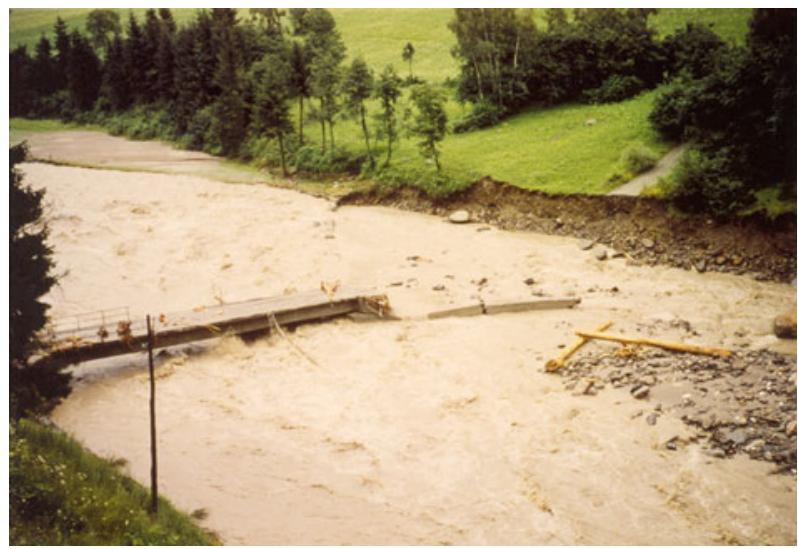

Fig. 12 Bridge destroyed across the Passer/Passirio river soon after the flood event in July 18th, 1987. The bridge was occluded with woody material and was destroyed after the outbreak of the river on the left side. The figure shows only the driftwood at the bridge that remained after the event

\section{Discussion and conclusions}

By the application of the developed method, valuable insights were provided regarding woody material recruitment processes and the propensity for entrainment and transport to critical configurations during extreme flood events. In particular, an overview of the 
maximal amount of transported and deposited woody material in a defined river reach was given. Moreover, the main pathways of the woody material in the river channel were traced and subsequently the potential depositional areas were identified. Furthermore, the procedure provided the order of dimension of the woody material volume expected to pass through bridges during a flood event. Such quantified knowledge on woody material volume approaching a weak point location is crucial for a reliable scenario definition during hazard assessment, in particular with respect to a possible log jam formation, clogging or similar obstruction phenomena. Consequently, the transparency of hazard mapping procedure and the quality of the results are increased, and the supervision of the entire hazard mapping procedure by the respective public authorities is facilitated. The outcomes can also be used in order to support the definition of policies in riparian forest management and for defining particular measures such as thinning and other forest management actions. Nevertheless, the procedure presented earlier might still have certain limitations. The spatial resolution of the flood simulation has to be adapted and refined if the goal is a more detailed scale. With a grid size of $10 \mathrm{~m}$, the river channel morphology is approximated with limited accuracy, resulting in a less precise calculation of the woody material flow paths. The procedure was found to be sensitive to the assumed wood stand volumes of different vegetation structures studied; however, a very detailed investigation on the wood structure might improve the procedure significantly. Additionally, the exposure time of the different vegetation structures to the flood event might be another relevant factor. During flood events with a relatively short duration, significantly smaller volumes are expected compared to long-duration flood events.

Despite these limitations, the developed method is of particular relevance to mitigate flood risk. The results of mapped recruitment areas with the respective forest structure typologies and identified transport paths with the transport dynamics for a determined critical configuration are essential indicators for hazard assessment.

The time-dependent modelling of woody material dynamics indicates whether or not the formation of log jams due to a simultaneous flooding of a large forested area with high flood intensities is plausible in the studied river reach. The assessment of the interaction processes induced at the considered critical configuration refines the hazard analysis and provides significantly more detailed input for the subsequent risk assessment. As shown during previous events, the critical configuration was repeatedly located at bridges; hence, the hypothetical debris accumulation for the entire bridge and the resulting consequences can be calculated according to the indications provided by Diehl (1997). This is fundamental information for effective risk mitigation strategies. Key elements of these strategies include: (1) the removal of those parts of the critical configuration that induce woody material accumulation, (2) the reconfiguration of the weak point to improve flow conditions and (3) the adherence to silvicultural measures in the respective recruitment areas in order to reduce the hazard source.

An application of the proposed model would allow enhanced emergency planning and preparations (e.g., excavating identified places in order to diminish accumulations at bridges; installation of temporary protection measures; implementation of local structural protection). These activities would introduce redundancies and buffer capacities into the system, thereby achieving an increased resilience of elements at risk.

Acknowledgments The development of the modelling approach was co-financed by the European Union within the Interreg IIIA project „Entwicklung eines Informationssystems für Naturraumpotentiale-Teil 2“. Afterwards, the procedure was refined within the Interreg IV B Alpine Space project "Adaptalp-Adaptation to Climate Change", also co-financed by the EU. The authors express their sincere thanks to the two 
anonymous reviewers and to Sven Fuchs and Francesco Comiti for valuable comments on an earlier version of the manuscript, to Emily Procter for improving the English manuscript and to Claudio Volcan for performing the hydrodynamic simulations.

Open Access This article is distributed under the terms of the Creative Commons Attribution Noncommercial License which permits any noncommercial use, distribution, and reproduction in any medium, provided the original author(s) and source are credited.

\section{References}

Abbe TB, Montgomery DR, Petroff C (1997) Design of stable in-channel wood debris structures for bank protection and habitat restoration: an example from the Cowlitz River, WA. In: Wang SSY, Langendoen EJ, Shields FD (eds) Management of landscapes disturbed by channel incision: stabilization, rehabilitation, restoration. University of Mississippi, Mississippi, pp 809-815

AIDI (Associazione Italiana di Idronomia) (2005) Procedura di calcolo dell'Idrogramma di piena a frequenza di superamento assegnata per il territorio della provincia Autonoma di Bolzano. Relazione tecnica, Bolzano

Autonome Provinz Bozen—Südtirol (2006) Richtlinien für die Erstellung von Gefahrenzonenplänen und zur Klassifizierung des spezifischen Risikos. Bozen

Bänziger R (1990) Schwemmholz im Unwettersommer 1987. Schweiz Ing Archit 47:1354-1358

Bezzola G, Sigg H, Lange D (2004) Schwemmholzrückhalt in der Schweiz. In: Internationales Symposion „Interpraevent 2004“, Riva, Trient; Tagungspublikation, Band 3, pp 29-40

Blaschke T, Tiede D, Heurich M (2004) 3D landscape metrics to modelling forest structure and diversity based on laser scanning data. In: The international archives of photogrammetry, remote sensing and spatial information sciences, vol XXXVI-8/W2, Freiburg, pp 129-132

Bocchiola D, Rulli MC, Rosso R (2006) Transport of large woody debris in the presence of obstacles. Geomorphology 76:166-178

Braudrick CA, Grant GE (2000) When do logs move in rivers? Water Resour Res 36(2):571-583

Braudrick CA, Grant GE (2001) Transport and deposition of large woody debris in streams: a flume experiment. Geomorphology 41:263-283

Braudrick CA, Grant GE, Ishikawa Y, Ikeda H (1997) Dynamics of wood transport in streams: a flume experiment. Earth Surf Process Landf 22:669-683

BUWAL-Amt für Raumplanung Graubünden-Ufficio Cantonale di Pianificazione (1998) Grundlage zur FAN-Tagung vom 13-16 Oktober 1998 in Ittingen, 15 pp

Comiti F, Andreoli A, Lenzi MA, Mao L (2006) Spatial density and characteristics of woody debris in five mountain rivers of the Dolomites (Italian Alps). Geomorphology 78:44-63

Curran JH, Wohl EE (2003) Large woody debris and flow resistance in step-pool channels, Cascade Range, Washington. Geomorphology 51:141-157

Degetto M (2000) Dinamica del legname in alveo e modellazione del suo comportamento in presenza di briglie filtranti. M.S. Thesis, University of Padova

Diehl TH (1997) Potential drift accumulation at bridges. Publication No. FHWA-RD-97-028 U.S. Department of Transportation, Federal Highway Administration Research and Development, TurnerFairbank Highway Research Center, Virginia

Egli T (2008) Wegleitung Objektschutz gegen meteorologische Naturgefahren. Vereinigung Kantonaler Feuerversicherungen VKF, Bern

Fuchs S, Holub M (2007) Risk management strategies for landslides in European mountain regions-current practice in Austria and future needs. Geogr Phorum 6:5-21

Fuchs S, McAlpin M (2005) The net benefit of public expenditures on avalanche defence structures in the municipality of Davos, Switzerland. Nat Hazards Earth Syst Sci 5(3):319-330

Gurnell AM, Petts GE, Hannah DM, Smith BPG, Edwards PJ, Kollmann J, Ward JV, Tockner K (2000) Wood storage within the active zone of a large European ravel-bed river. Geomorphology 34:55-72

Haga H, Kumagai T, Otsuki K, Ogawa S (2002) Transport and retention of coarse woody debris in mountain streams: an in situ experiment of log transport and a field survey of coarse woody debris distribution. Water Resour Res 38:8

Hildebrand RH, Cemly AD, Dolloff CA, Harpster KL (1997) Effects of large woody debris placement on stream channel and benthic macroinvertebrate. Can J Fish Aquat Sci 54:931-939

Holub M, Hübl J (2008) Local protection against mountain hazards-state of the art and future needs. Nat Hazards Earth Syst Sci 8:81-99 
Hübl J, Anderschitz M, Florineth F, Gatterbauer H, Habersack H, Jäger E, Kogelnig A, Krepp F, Rauch JP, Schulev-Steindl E (2008) FLOODRISK II-Vertiefung und Vernetzung zukunftsweisender Umsetzungsstrategien zum integrierten Hochwasserschutz, Workpackage 2.3-Präventive Strategien für das Wildholzrisiko in Wildbächen. Bundesministerium für Land- und Forstwirtschaft, Umwelt und Wasserwirtschaft, Abteilung IV/5, Wildbach und Lawinenverbauung, 43

Keim RF, Skaugset AE, Bateman DS (2002) Physical aquatic habitat: II. Pools and cover affected by large woody debris in three western Oregon streams. North Am J Fish Manag 22:151-164

Klosterhuber R, Plettenbacher T, Hotter M, Schober T, Aschaber R, Vacik H, Pircher G, Gruber G, Ruprecht H (2007) Ökologisches Handbuch zur Waldtypisierung und Waldstratifizierung Südtirol, Teil A, Zwischenbericht im Auftrag der Autonomen Provinz Bozen, Abteilung 32, Forstwirtschaft. Bozen

Lange D, Bezzola GR (2006) Schwemmholz, Probleme und Lösungsansätze, Mittelungen der Versuchsanstalt für Wasserbau, Hydrologie und Glaziologie (VAW), Zurich

Lyn D, Cooper T, Condon D, Gan L (2007) Factors in debris accumulation at bridge piers, Washington, US Department of Transportation, Federal Highway Administration Research and Development, TurnerFairbank Highway Research Center

May CL, Gresswell RE (2003) Large wood recruitment and redistribution in headwater streams in the southern Oregon. Coast Range, USA. Can J For Res 33(6):1352-1362

Mazzorana B, Zischg A, Largiader A, Hübl J (2009) Hazard index maps for woody material recruitment and transport in alpine catchments. Nat Hazards Earth Syst Sci 9:197-209

Mitchell JK (2003) European river floods in a changing world. Risk Anal 23:567-574

Montgomery DR, Piegay H (2003) Wood in rivers: interactions with channel morphology and processes. Geomorphology 51:1-5

Ng YLA, Richardson JR (2001) Transport mechanics of floating woody debris. Thesis, Faculty of the Graduate School, University of Missouri-Columbia

Oberndorfer S, Fuchs S, Rickenmann D, Andrecs P (2007) Vulnerabilitätsanalyse und monetäre Schadensbewertung von Wildbachereignissen in Österreich. BFW, Wien

Petraschek A, Kienholz H (2003) Hazard assessment and mapping of mountain risks in Switzerland. In: Rickenmann D, Chen CL (eds) Debris-flow hazard mitigation: mechanics, prediction and assessment. Millpress, Rotterdam

Rauch HP (2005) Hydraulischer Einfluss von Gehölzstrukturen am Beispiel der ingenieurbiologischen Versuchsstrecke am Wienfluss. Dissertation, University of Life Sciences Vienna, Vienna

Rickenmann D (1997) Schwemmholz und Hochwasser. Wasser Energ Luft 5(6):115-119

Rickli C, Bucher H-U (2006) Schutzwald und Schwemmholz in Wildbacheinzugsgebieten. In: FAN-Agenda 1/06, pp 17-20

Rimböck A, Strobl T (2002) Loads on rope net constructions for woody debris entrapment in torrents. International Congress "Interpraevent 2002 in the Pacific Rim", Matsumoto, Japan; Congress publication, vol 2, pp 797-807

Shields FD, Morin N, Kuhnle RA (2001) Effects of large woody debris structures on stream hydraulics. In: Proceedings of wetlands engineering and river restoration conference, ASCE, Reston

Wilson CAME, Yagci O, Olsen NBR, Rauch HP (2004) 3D numerical modelling of vegetated compound channel flows. In: IAHR/IWA 6th international conference on hydroinformatics, Singapore

WL Delft Hydraulics (2004) Release notes, SOBEK version v2.09.001. Delft 